Papers and Proceedings of the Royal Society of Tasmania, Vo1.109, 1975.

(ms. received 16.10.1974)

\title{
HETERIAS PETRENSIS, A NEW SPECIES OF FRESHWATER ISOPOD \\ FROM TASMANIA (FAMILY JANIRIDAE, TRIBE ASELLOTA)
}

by P.C. Roberts

Department of Zoology, University of Tasmania

(with one table and eight text-figures)

\section{ABSTRACT}

A new species of freshwater isopod, Heterias petrensis (Family Janiridae, tribe Asellota) is described. The species is found in Lake Crescent, Tasmania. A revised description is given of the genus Heterias.

\section{INTRODUCT ION}

Although the isopod family, Janiridae, contains a predominance of entirely marine genera, freshwater genera have been described from South Africa (Barnard 1927, 1955; Grindley 1963), South America (Muller 1892) and the Bassian regions of southeastern Australia (Sayce 1900, Chappuis 1951).

Sayce (1900) described a collection of blind janirids (Janirelza pusizza) from a freshwater pool at Thorpdale, Gippsland, Victoria. The generic name Janirella was however unavailable, since Bonnier (1896) had used it previously to describe a new species of marine asellid and Richardson (1904), recognizing this, proposed Heterias as a replacement.

Chappuis (1951) described a blind janirid similar to Heterias pusizla, collected from the Guide River in northern Tasmania. These animals he designated Pseudasellus nichollsi, a new species and genus, apparently overlooking Sayce's (1900) description of Janirezza. Williams (1968) suggested that Pseudaselzus nichollsi may be congeneric or conspecific with Heterias pusilza.

The genus Protojanira was described from South Africa by Barnard (1927). He described the species Protojanira prenticei in 1927 and Protojanira perbrincki in 1955. Grindley (1963) described Protojanira Zeleupi from South Africa and discussed the main characters of the genus. A11 three species are blind freshwater janirids from pools in caves. Wolff (1962) placed a freshwater janirid from Brazil, Janiropsis exul (Muller 1892) in the genus Heterias because of its close resemblance to Heterias pusizla (Sayce 1900). Hutchinson (1967) noted the similarity between Protojanira from South Africa and Heterias from Victoria.

\section{HETERIAS Richardson, 1904}

The head bears a slight convexity suggestive of a rostral process; eyes present or absent; body oblong ovate; antennules consist of a three-jointed protopodite and a three-jointed flagellum; antennae either of greater length than the body or just less; a squama is present on the third segment of the antennae; pereonites 1-7 with smooth, rounded, setaceous lateral margins; coxae invisible from above; pereopods are al1 ambulatory and similar in both sexes; dactyli of peropods are bi-unguiculate, terminating in a long simple unguis, near which is a smaller lateral one; uropoda are well developed, cylindriform, biramous and shorter than the pleotelson; the first male pleopod is elongate and only slightly dilated at the base; the second male pleopod bears a thread-1ike endopodite, which is spiral and much longer than the pedunc1e; 


\section{New Freshwater Isopod from Tasmania}

pleopods III and IV are biramous and similar in both sexes; pleopod V is uniramous and similar in both sexes; the pleon is composed of two segments, the first narrow and inconspicuous, the second large and shield shaped.

HETERIAS PETRENSIS n. sp.

\section{Type Materia1}

Holotype: mature male; lodged in Australian Museum, Sydney, No. P20097.

Allotype: mature female; lodged in Australian Museum; No. 20098.

Paratypes: 15 mature males; lodged in Australian Museun; No. 20099.

15 mature fenales; lodged in Australian Museum; No. 20100.

15 juveniles; lodged in Australian Museum; No. 20101.

15 mature males; lodged in Tasmanian Museum and Art Gallery, Hobart; No. G1574.

15 mature females; 1odged in Tasmanian Museum and Art Galley; No. G1572. 15 juveniles; lodged in Tasmanian Museum and Art Gallery; No. G1573.

A11 specimens collected in Lake Crescent, Tasmania, by P.C. Roberts on 30.5.1972.

General Characters of the Species

The female is larger than the male, being widest at its sixth thoracic segment (pereonite). The male is widest at its seventh thoracic segment. In most other respects, the male and female are similar, except in the morphology of the pleopods. The pereonites have smooth round lateral margins, which overhang the pereopods. The eyes are situated on the dorso-1ateral margin of the head. The antennules are much shorter than the antennae and consist of a three-jointed protopodite and a flagellum composed of three segments. The antennae are longer than the bociy and are composed of a six-jointed protopodite and a multiarticulate flagellum. A scale-like exopodite (squama) is present on the third segment of the protopodite which bears three apical setae. The outer lobe of the first maxillae bears 10-12 pectinated setae at its distal margin. The two outer lobes of the second maxillae bear a distal row of four finely pectinated setae. The apical dentary process of the mandibles comprises in the male, on the left, one lobe of six teeth, and on the right, one lobe of six teeth plus a lacinia mobilis of six teeth. The female bears on the left, one lobe of five teeth, and on the right one lobe of five teeth plus a lacinia mobilis of five teeth. The maxillipeds are of the normal janirid structure. The pereopods are composed of seven joints, are all ambulatory and are similar in both sexes. All dactyli are bi-unguiculate. The uropods are well developed, cylindrical, attached termolaterally to the pleotelson and composed of three parts, protopodite, exopodite and endopodite. The exopodite of the uropod is shorter than the endopodite but longer than the protopodite. The pleopods are normally developed, the base of the sympode of the first male pleopod is slightly dilated at the base.

\section{Descriptive Notes}

The size ranges (rostral projection to end of pleotelson) are for males, 1.58 to $3.67 \mathrm{~mm}$, and for females, 1.58 to $4.02 \mathrm{~mm}$. The average length of males varied from $2.18 \mathrm{~mm}$ in February to $2.74 \mathrm{~mm}$ in September, whereas the average length of females varied from $2.30 \mathrm{~mm}$ in February to 2.89 in September. According to Chappuis (1951) the length of an adult male, Pseudaselzus nicholzsi, was $1.5 \mathrm{~mm}$, whereas the adult female was $7 \mathrm{~mm}$. Since type material of $P$. nicholzsi was unobtainable, it is possible that the length of $7 \mathrm{~mm}$ for the female is a typographical error, since the measurement of $7 \mathrm{~mm}$ is several times greater than that of other heteriads.

The following descriptive notes of Heterias petrensis are of mature males, but they are also applicable to a mature female, except where otherwise stated. 


\section{P.C. Roberts}

The adult male has the same general appearance as the adult female. The body is oblong-ovate and dorsoventrally compressed. It consists of differentiated segments, with the segments arranged into three obvious groups; head, thorax (pereon) and abdomen (pleon or pleotelson) (fig. 1).

The greatest width of the male is across pereonite seven, whereas the female is widest across pereonite six. $H$. petrensis is pigmented and mottled brown in colour. Pigment is often lacking from the distal extremities of the antennae, antennules, pereopods and uropods and the ventral side of the body.

Head: The antero-dorsal edge of the head is not straight but has a slight convexity suggestive of a rostral process (fig. 1). The anterior part of the head bears two paired appendages: antennules (first antennae) and antennae (second antennae).

(a) Eyes: The sessile eyes are slightly raised above the level of the head and are situated on the dorso-lateral margins of the head. They are composed of many ommatidia.

(b) Antennules (Figure 2a): The antennules are much shorter than the antennae or the head and consist of a three-jointed protopodite and a flagellum composed of three joints. The basal joint of the protopodite is very stout, being at least twice as long and twice as wide as the second joint. The second joint is twice as wide and slightly longer than the remaining joints of the antennule, which are oblong in shape. The antennule bears simple setae and several plumose setae on its apical and lateral margins.

(c) Antennae (Figure 2b): The antennae are longer than the body. The antenna length to body length ratios are 1.2:1.0 for both males and females. The base of the antenna is composed of 6 segments of differing lengths. The first three segments are sub-quadrate and are approximately equal in size. The third segment is the longest and widest of these three segments and a scale-like exopodite (squama) is present on its outer margin bearing three apical setae. The fourth segment is ha1f the length of the third segment and not as wide. The fifth segment is longer than the first three segments combined and is not as wide as the fourth segment. The sixth segment is the longest and narrowest segment of the base of the antennae. The

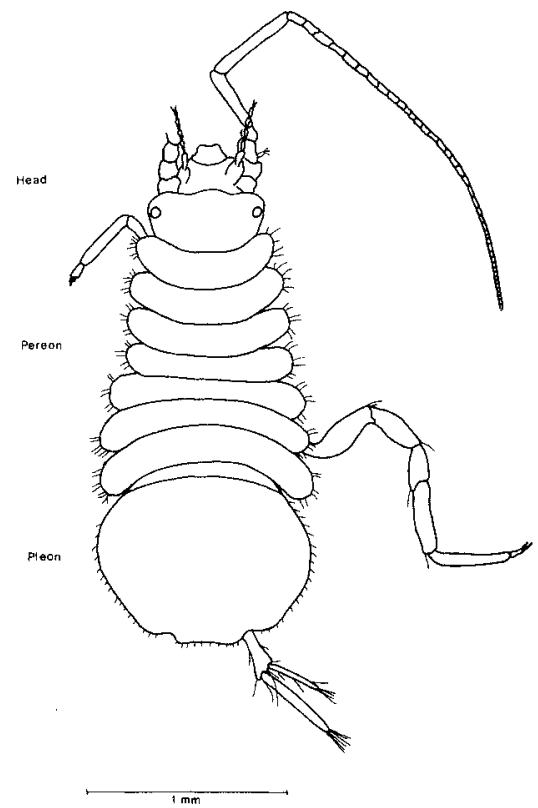

FIG. 1. - Heterias petrensis dorsal view, male. segments composing the flagellum are rectangu1ar.

The number of segments composing the flagellum varies according to body length. In a sample of twenty three males, the number of segments of the antenna varied from 20 to 47 with a mean of $38.13+7.08$ and for females it varied from 27 to 45 with a mean of $35.3 \pm 5.38$. The antennae bear simple setae on their lateral margins and a single seta on their apex.

Mouthparts: The mouthparts are situated sub-terminally on the ventral side of the head and consist of a pair of mandibles, two pairs of maxillae, a pair of maxillipeds and an unpaired upper and lower lip. Except for minor differences the mouthparts are identical on each side and there is very little difference between the sexes, except in the mandibles. 


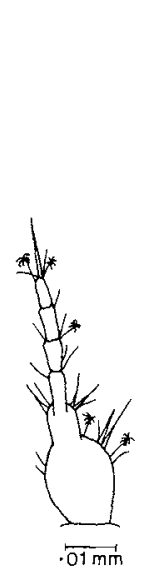

a

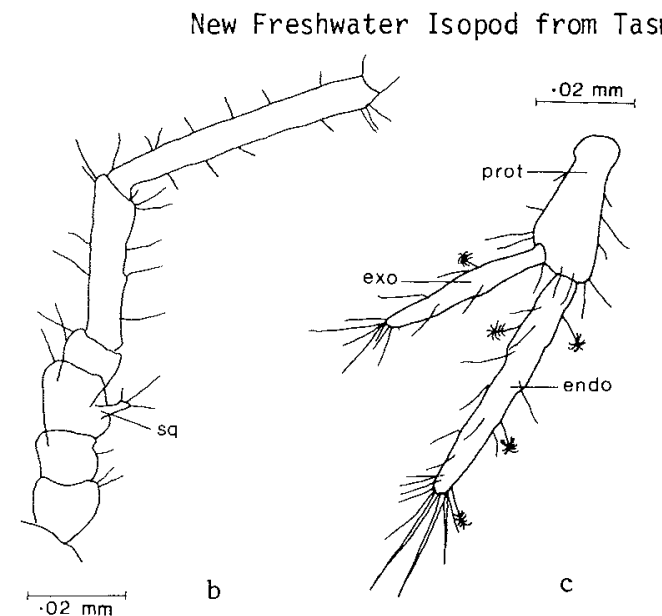

2b. - antenna; sq-squama.

FIG. 2a. - ant ennule.

2c. - uropod; prot-protopodite, exo-exopodite, endo-endopodite.

2d. - pereopod; dac-dactylus, pro-propodite.

(a) Mandibles (Figure 3): The mandibles are situated laterally to the oral opening and consist of a three-jointed palp, molar process, mandibular body, apical dentary process and on the right mandible only, a lacinia mobilis. The first joint of the palp is oblong in shape, and is widest at its apical end. The second joint is wider and longer than the first joint and bears seven doubly-pectinated setae on its internal margin; the second and seventh setae are twice the length of the others. The third joint of the palp is of similar length to the first joint and is slightly bent backwards towards the base with the end rounded and bearing on its medial margin 18 doubly-pectinated setae which decrease in length distally. The molar process has parallel sides and is well developed with a truncated, ridged, apex. The mandibular body bears a row of thirteen setae at its apical margin, of which the first three are pectinated and the remaining ten simple. The apical dentary process comprises in the male, on the 1 eft, one lobe of six teeth, and on the right one lobe of six teeth plus a lacinia mobilis of six teeth. The female bears on the left, one lobe of five teeth and on the right one lobe of five teeth plus a lacinia mobilis of five teeth. The hinge line of the mandibles is straight without any further special articulating surfaces.

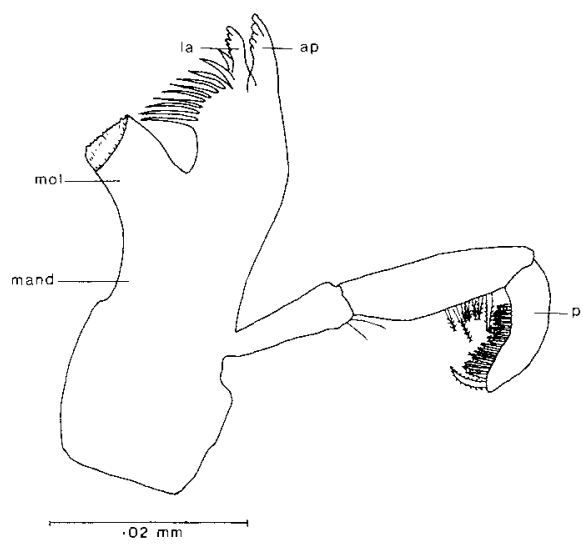

FIG. 3. - mandible - right, female; ap-apical dentary process, la-lacinia mobilis, molmolar process, mand-mandibular body, p-palp. (b) Maxilla I (Figure 4b): The first maxillae are each composed of two lobes, the inner lobe is slightly shorter than the outer lobe and bears about its distal margin a large number of simple setae. The outer lobe bears ten to twelve stout pectinated setae at its distal extremity. Both lobes bear setae on their anterior and posterior margins .

(c) Maxil1a II (Figure 4a): The second maxillae are each composed of three lobes, one inner and two outer lobes, all three lobes arising from a common base. The inner lobe is densely covered with simple setae on its distal and posterior margins and also bears a single plumose seta amongst the simple setae on its distal margin. The two outer lobes are slightly narrower than the inner lobe and each bears a distal row of four finely-pectinated setae, and several simple setae on their posterior margin. According to Birstein (1964), "in all probability the outer lobes of the first and second maxillae correspond to the exopodites and the inner lobes to the outgrowths of the protopodites, while the endopodites are absent". 


\section{P.C. Roberts}

(d) Maxillipeds (Figure 4c): The maxillipeds are fused to each other at their base and cover all the mouthparts from below. Each maxilliped is composed of four parts; base (coxa), body (masticatory lobe), five-jointed palp and epipodite.

The base consists of two segments, coxa and precoxa. The coxa is small and triangular (fig. $4 \mathrm{c}$ ), beside which is the precoxa (fig. 4c). The masticatory lobe bears two teeth on its inner distal margin and many simple setae on its distal margin. The palp is composed of five joints, differing in length and width. The first joint is a third as long as the second and the same width as the base of the second joint. The second joint is long and twice as broad at its distal end. The third joint is shorter and narrower than the second joint. The fourth joint is long and narrow, being slight1y longer than the second joint and half the width of the distal end of the second joint. The fifth joint is approximately half the length and half the width of the fourth joint. All five joints have setaceous margins and the fifth joint bears a tuft of setae on its apical margin. The majority of these setae are much stouter than those on the masticatory lobe. The epipodite is large, welldeveloped, irregularly ovate and attached to the base of the coxa. In the male the outer edge is concave, whereas it is straight in the female.
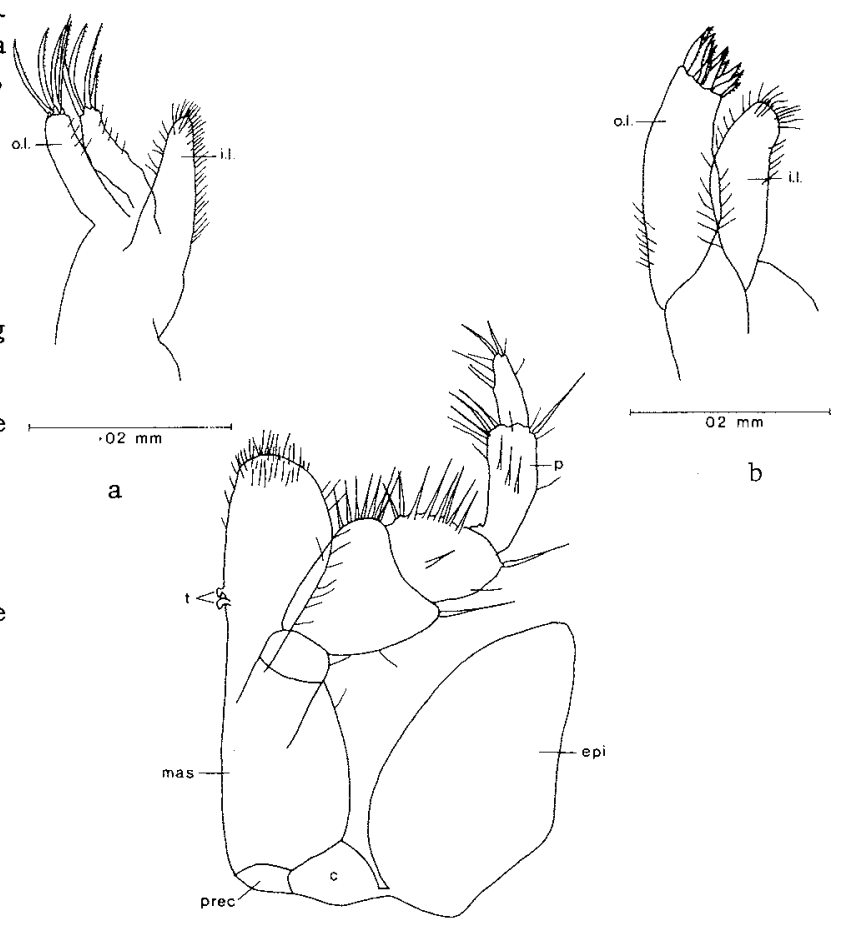

(e) Upper Lip: The upper lip

bearing a row of setae at its distal end is evenly rounded and divided by a transverse line which runs from margin to margin.

(f) Lower Lip: The lower lip bearing setae in tufts on its distal margins is divided longitudinally into 2 lobes by a narrow triangular slit.

Pereon: The pereon consists of seven movable segments (pereonites). The pereonites are of approximately equal length but increase in width towards the pleotelson. In the male the seventh pereonite is the widest, whereas in the female the sixth pereonite is the widest, the seventh pereonite being of approximately the same width as the fifth. The pereonites have smooth lateral margins bearing several simple setae, and overhang the pereopods. Each pereonite bears a pair of pereopods.

(a) Pereopods: The pereopods are composed of 7 joints, all ambulatory and similar to each other in both sexes. They differ only in the length of their joints, and they increase in length posteriorly.

The dactylus (fig. 2d) is crescent-shaped, long and thin, and about one quarter the 1 ength of the propodite. All the dactyli are bi-unguiculate, terminating in a long 
New Freshwater Isopod from Tasmania

simple unguis and on the inner margin, at its base is a smaller lateral unguis. The carpopodite is of the same length as the propodite but slightly wider. The meropodite is triangular and widest at its distal end, being just wider than the carpopodite and about half the length of the carpopodite. The ischiopodite is about the same length as the carpopodite, is widened medially and is of the same width as the meropodite. The basipodite is widened medially and is the same width as the ischiopodite but of greater length. The coxopodites are very small and fused along their basal margin to the lateral edge of the sternite of the thoracic segment. Sayce (1900) depicted the coxopodites as distinct entities, whereas Chappuis (1951) failed to mention them. All the pereopods are setaceous, bearing strong two-pointed setae on their internal margin plus very short fine setae and long fine setae on their outer margin. Plumose setae are present on the distal angle of the propodite and the carpopodite and the centre of the basipodite in the male; whereas, the female bears plumose setae only on the propodite and the carpopodite. Ovigerous females bear oostegites on the coxopodites of the first four pereonites, which together construct the brood pouch. The first two are small and ovate, the third is twice their size and the fourth is slightly smaller than the third. The oostegites do not overlap.

pleon: The pleon consists of two somites, the first is narrow and inconspicuous, whilst the second is shield shaped and large. The pleon bears six pairs of limbs five pairs of pleopods and a pair of uropods. In the female, the first pair of pleopods is absent. As yet is has not been possible to associate the limbs with the appropriate somite.

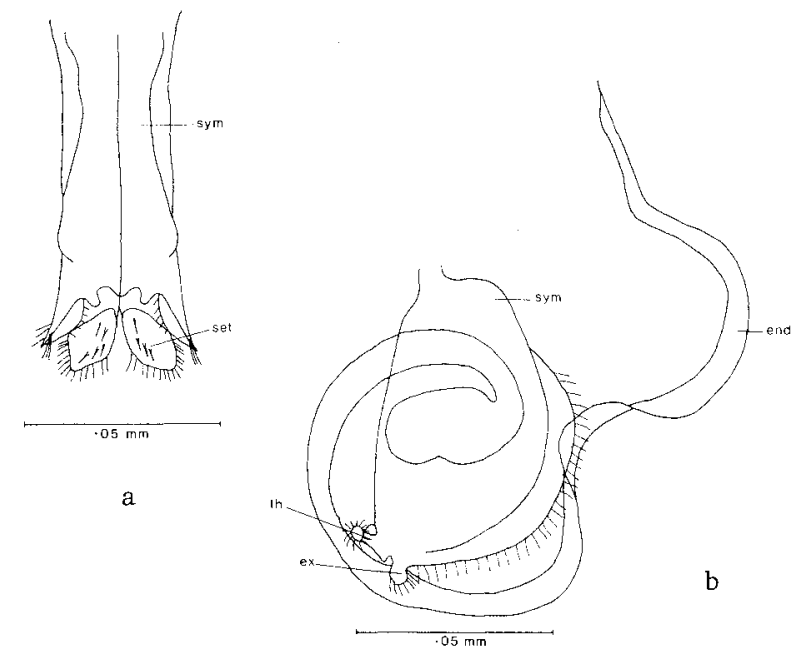

(a) Pleopod I - Male (Figure 5a): The first male pleopod consists of an elongated sympode, which is slightly dilated at the base and bears one pair of setaceous lobes. In $H$. petrensis there appears to be an inner lobe comparable with the structure described by Chappuis (1951)(fig. 14, p. 14 of his paper) as a bristly lobe. On dissection of $H$. petrensis, this lobe is found to be a structure within the pleopod. The first pair of pleopods is coupled with the second pair forming a tripartite operculum covering the remaining pleopods which are respiratory.

FIG. 5a. - pleopod I - male; sym-sympode, setsetaceous lobe.

5b. - pleopod II - male; end-endopodite, sym-sympode, ex-exopod, th-third structure. Depiction of the muscle structure is deleted to avoid confusion.

(b) P1eopod II - Male (Figure 5b): The second pleopod consists of a large sympode with the external margin convex and the internal margin straight. The external margin is fringed with simple setae. On the centre of the posterior side of each pleopod is the endopodite (appendix masculina), which is spiral in form and at least five times the length of the pleopod. The endopodite appears to be hollow, except for a chitinous reinforcement running along its external margin. The endopodite terminates in a fine point. The exopodite is reduced to a small projection bearing setae inserted on the apical margin of the pleopod. A third structure is present on the internal apical margin of the pleopod and it is fringed with setae. This structure was not mentioned by either Sayce (1900) or Chappuis (1951). It appears to 


\section{P.C. Roberts}

be a definite structure inserted inside a cavity. In live specimens, it is often protruded. Its function at this time is unknown, but it may be a copulatory structure, since a penial stylet (Chappuis 1951) was not found between the seventh pereopods such as that of Pseudasellus nichollsi. The sympode is highly muscular, possessing many muscle bands which are attached to the external and apical margin of the sympode. At 1 east one muscle band is isolated from this system and links the base of the endopodite to the base of the protruding structure.

(c) Pleopod II - Female (Figure 6a): Both pleopods of the second pair are fused without a trace of a suture to form a common operculum, which completely covers the following pairs of pleopods. The pleopod is round, with a rounded median protruberance at its dista1 extremity, and has a setaceous margin. A row of setae is present on either side of the median line and a second row of setae is present just inside the distal margin.

(d) Pleopod III (Figure 7a): The third pleopod is biramous and similar in both sexes. It bears a well developed exopodite which is one third longer and wider than the endopodite. The exopodite is divided into two sections by a suture and has a setaceous margin. At its apical extremity the exopodite bears one or two strong simple setae. The endopodite is not divided by sutures and lacks setae.

(e) Pleopod IV (Figure 7c): The fourth pleopod is biramous and similar in both sexes. The exopodite is one third longer and one third wider than the endopodite. The exopodite tapers distally and terminates in a rounded tip, which bears severai simple setae. Setae are slo present on the internal margin of the exopodite. The endopodite is oblong-ovate and lacks setae.

(f) Pleopod V (Figure 7b): The fifth pleopod is uniramous and similar in both sexes. It is composed of a protopodite and an oval endopodite. The exopodite is absent. The endopodite is non-setaceous.

(g) Uropods (Figure 2c): The uropods are attached termo-1aterally to the pleotelson. Each is cylindrical and composed of three parțs, protopodite (peduncle), exopodite (outer ramus) and endopodite (inner ramus). The uropods are just shorter than the pleotelson. The ratios of uropod length to pleotelson length are, $1: 1.32$ for males and 1:1.22 for females. The endopodite is longer than the exopodite, which is longer than the protopodite. The ratios of endopodite length to exopodite length to protopodite length are 7.52:5.12:4 for males and 7.86:4.81:4 for females. The uropods bear setae on their lateral margins and a tuft of seven setae on the distal ends of the exopodite and endopodite. Several plumose setae are present on the lateral margins of the endopodite and one on the lateral margin of the exopodite.

(h) Intersexes (Figure 6b): Among the specimens examined, intersexes, predominantly bearing female characteristics were not infrequently found. The first male pleopod was more or less developed, but was never as differentiated as that of the adult male. 
The second pleopod was of a similar shape to the female operculum. The pleopod is transparent and lobes are clearly visible. Similar intersexes were found by Chappuis (1951) in Pseudasezlus nicholzsi and he tentatively suggested that these lobes represent the endopodite and exopodite of the second male pleopod.
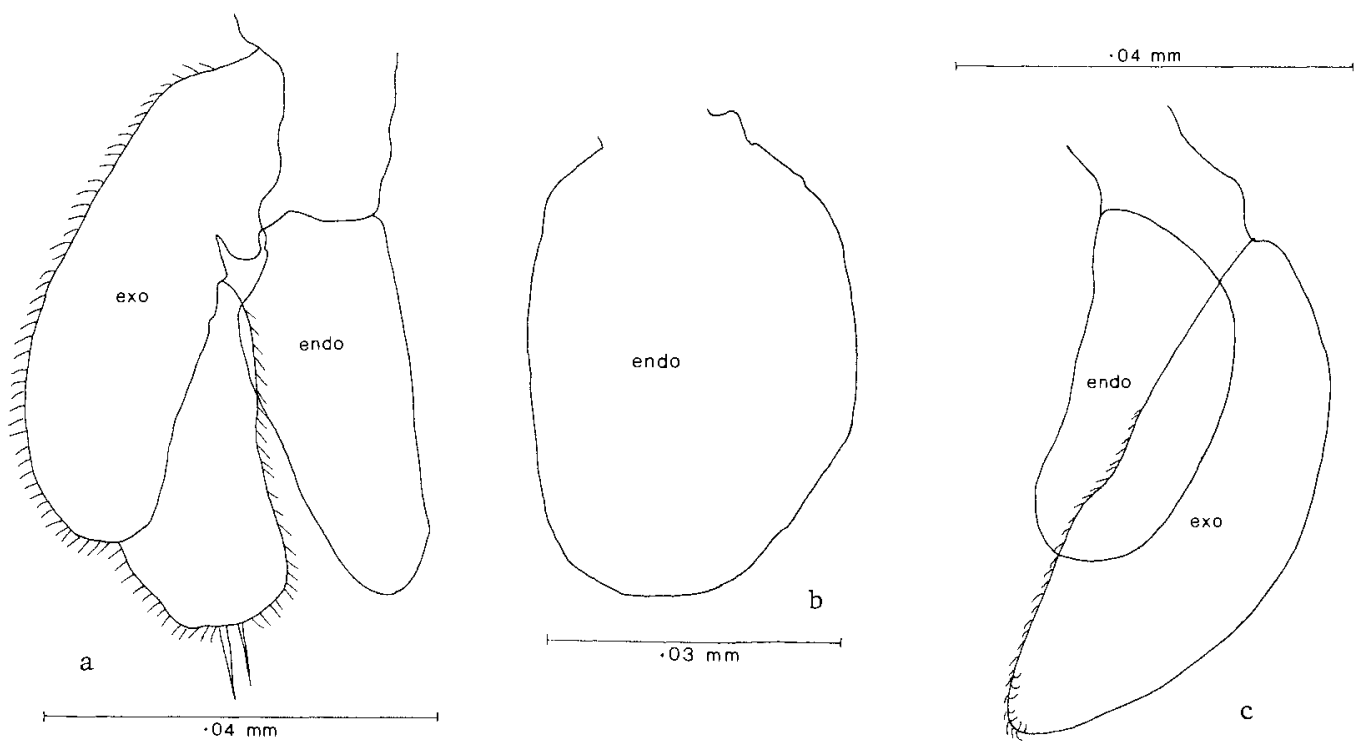

FIG. 7a. - pleopod III - male; endo-endopodite, exo-exopodite.

7b. - pleopod V - male; endo-endopodite, exo-exopodite.

7c. - pleopod IV - male; endo-endopodite, exo-exo-exopodite.

\section{REMARKS}

The most noticeable differences between Heterias petrensis and Heterias pusizza are summarized in table 1 .

As a result of comparing $H$. petrensis with $H$. pusizza it appears that they are similar in enough characters to be considered as belonging to the same genus, Heterias (Sayce 1900). However they warrant being considered as different species.

H. petrensis from Lake Crescent 1 ives on the underside of rocks in 1 ess than $30 \mathrm{~cm}$ of water, being most abundant in water less than $15 \mathrm{~cm}$ in depth. H. petrensis is herbivorous, feeding on algae and possibly on dead and decaying leaves. The species is also found in Lake Sore11.

The new species, Heterias petrensis possesses many characters similar to Heterias pusilza, Heterias exul and Pseudasellus nichollsi as well as possessing characters dissimilar from each.

From H. pusizza, H. petrensis differs in (1) the form of the male and female, (2) the presence of eyes, (3) the exopodite of the uropoda are not shorter than the peduncle but longer than the peduncle, (4) the shape of the base of pleopod I (see figs. $5,8 \mathrm{~d}$ ).

From H. exul, H. petrensis differs in (1) the form of the male and female, (2) the 
P.C. Roberts

TABLE 1

Some major differences between Heterias petrensis and $H$. pusizza

\begin{tabular}{|c|c|c|}
\hline & II. petrensis & H. pusizza \\
\hline Eyes & present & absent \\
\hline $\begin{array}{l}\text { Widest segment - } \\
\text { female } \\
\text { male }\end{array}$ & $\begin{array}{l}\text { sixth pereonite } \\
\text { seventh pereonite }\end{array}$ & $\begin{array}{l}\text { third pereonite } \\
\text { pleotelson }\end{array}$ \\
\hline \multirow[t]{2}{*}{ Mandibular palp } & $\begin{array}{l}\text { setae on } 2 \text { nd joint doubly } \\
\text { pectinated }\end{array}$ & $\begin{array}{l}\text { setae on } 2 \text { nd joint "spatulate } \\
\text { with margins delicately feathered" }\end{array}$ \\
\hline & $\begin{array}{l}3 \text { rd joint of the palp } \\
\text { bears one strong1y } \\
\text { doubly-pectinated } \\
\text { setae at its distal end } \\
\text { and } 18 \text { doubly-pectinated } \\
\text { setae. }\end{array}$ & $\begin{array}{l}\text { 3rd joint of the palp bears } \\
\text { "three plumose setae, and six } \\
\text { short stout plumose setae". }\end{array}$ \\
\hline Dactylus & $\begin{array}{l}\text { secondary claw just shorter } \\
\text { than major claw. }\end{array}$ & secondary claw extremely small. \\
\hline Uropods & $\begin{array}{l}\text { exopodite longer than the } \\
\text { peduncle. }\end{array}$ & $\begin{array}{l}\text { exopodite is very short, } \\
\text { shorter than the peduncle. }\end{array}$ \\
\hline Pleopod I & see diagram fig. $5 a$. & see diagram fig. $8 \mathrm{~d}$ \\
\hline Pleopod III & $\begin{array}{l}\text { exopodite one third wider } \\
\text { and longer than endopodite. }\end{array}$ & $\begin{array}{l}\text { exopodite } 3 x \text { wider and } 2 x \\
\text { longer than endopodite. }\end{array}$ \\
\hline Pleopod IV & $\begin{array}{l}\text { exopodite one third wider } \\
\text { and longer than endopodite. }\end{array}$ & $\begin{array}{l}\text { exopodite } 2 \mathrm{x} \text { wider and } 1 \frac{1}{2} \mathrm{x} \text { longer } \\
\text { than endopodite. }\end{array}$ \\
\hline Pleopod V & oval. & oblong ovate. \\
\hline
\end{tabular}


extent of the expansion of the distal end of pleopod I (see figs. 5a, 8c), (3) the extent of the elongation of the endopodite of male pleopod II (figs. $8 \mathrm{a}, 5 \mathrm{~b}$ ).

From $P$. nicholzsi, H. petrensis differs in (1) the form of the male and female, (2) the presence of eyes and body pigmentation, (3) the antennae length is not less than, but greater than body length, (4) the exopodite of the uropod is not shorter than but longer than the peduncle, (5) pleopod I does not bear two pairs of bristly lobes at the base of the pedunlce, but one pair of setaceous lobes, (6) the form of the male pleopod II (figs. 8b, 5b).

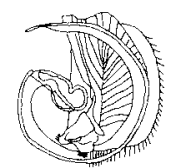

a

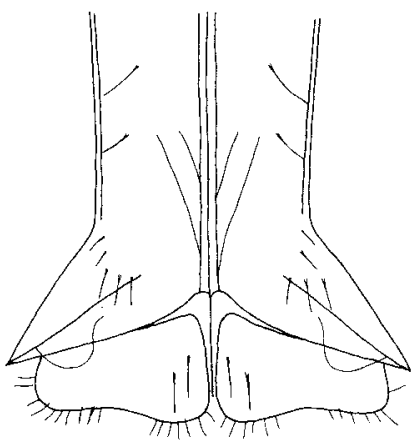

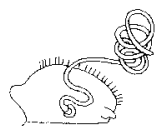

c

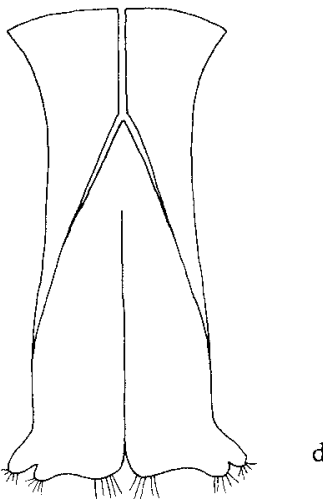

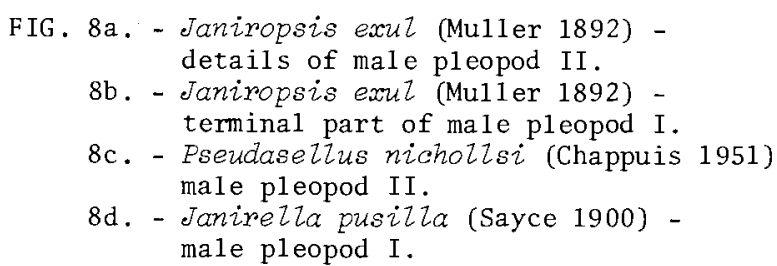

\section{AC KNOWLEDGEMENTS}

The author wishes to thank Dr. P.S. Lake of the Department of Zoology, University of Tasmania for encouragement and guidance during this study; Mr. B. Knott of the Department of Zoology, Murdoch University, Western Australia, for assistance with taxonomy and Mrs. T. Vasos of the Department of Zoology, University of Tasmania for typing the manuscript. The author is indebted to the technical assistance of Mrs. N. Dorney, of the Department of Zoology, University of Tasmania. 


\section{P.C. Roberts}

\section{REFERENCES}

Barnard, K.H., 1927: A study of the freshwater isopodan and amphipodan crustacea of South Africa. Trans. Roy. Soc. South Africa, 14, 139-215. 1955: A new Protojanira from Natal (Isopoda, Asellota). Ann. Natat Mus., 13, 249-251.

Birstein, Y.A., 1964: Freshwater Isopods. (Asel1ota). FAUNA OF U.S.S.R. CRUSTACEA. $7(5)$, translated for the Smithsonian Institution and the National Science Foundation, Washington, D.C. by the Israel Program for Scientific Translations.

Bonnier, J., 1896: Edriophtha1mes. Resultats scientifiques de 1a campagne du "Candan" dans le Golfe du Gascogne. Ann. Univ. Lyon., 26, 527-689.

Chappuis, P.A., 1951: Un nouveau parase11ide de Tasmania, PseudaselZus nicholZsi. Arch. Zool. Exp. Gen., 88, 7-19.

Grindley, J.R., 1963: A new Protojanira (Crustacea, Isopoda) from a Cape Penisula Cave. Ann. Transvaal. Mus., 24, 271-274.

Hutchinson, G.E., 1967: A TREATISE ON LIMNOLOGY. Volume 2. Wiley and Sons, New York.

Muller, F., 1892: Descripcao de Janira exul, Crustaceo Isopode do Estado de Santa Catharina. Archiv. do Museo Nacional Rio de Janeiro. 8, 209-220.

Richardson, H., 1904: Contributions to the Natural History of the Isopoda. Eroc. U.S. Nation. Mus., 27, 1-89.

Sayce, O.A., 1900: Janirella, a new Genus of Isopoda from freshwater, Victoria. Proc. Roy. Soc. Vic., 13, 124-130.

Wi11iams, W.D., 1968: AUSTRALIAN FRESHWATER LIFE. THE INVERTEBRATES OF AUSTRALIAN INLAND WATERS. Sun Book, Melbourne.

Wo1fe, T., 1962: The Systematics and biology of bathyal and abyssal Isopoda Asellota. Galathea. Rep., 6, 1-315. 
